\title{
The genesis and evolution of subcontinental lithospheric mantle beneath Botswana and N. South Africa.
}

\author{
G.R. Davies ${ }^{\mathrm{a}}$, Q. van der Meer ${ }^{\mathrm{b}}$, M. Klaver ${ }^{\mathrm{c}}$, A.M. Borst ${ }^{\mathrm{d}}$, B. Davidheiser ${ }^{\mathrm{e}}$, T.J. Meulemans ${ }^{\mathrm{f}}, \mathbf{S}$. \\ de Jong ${ }^{g}$, C.S. Nooitgedacht ${ }^{\mathrm{h}}$, C.M. de Heij ${ }^{\mathrm{i}}$ \\ ${ }^{a}$ Vrije Universiteit, De Boelelaan 1085, 1081 HV Amsterdam, The Netherlands, g.r.davies@vu.nl; \\ ${ }^{b}$ qvandermeer@gmail.com; ${ }^{c}$ martijn.klaver@bristol.ac.uk; ${ }^{d}$ amb43@st-andrews.ac.uk; \\ ${ }^{e}$ Brett.Davidheiserkroll@colorado.edu; ${ }^{f}$ tmeulem@gmail.com; ${ }^{g}$ sharon90_8@hotmail.com; \\ ${ }^{h}$ cas_nooitgedacht@outlook.com; ${ }^{i}$ carlijndeheij@gmail.com.
}

\section{Introduction}

The processes that led to the formation and stabilisation of sub continental lithospheric mantle (SCLM) remain a matter of debate (e.g., Pearson \& Wittig, 2014; Aulbach et al., 2017). Resolving this question is required to determine how the SCLM is subsequently modified over time and to establish possible links between specific events within the mantle and diamond formation. This project reports on a project designed to obtain an integrated view of the SCLM beneath the north-west portion of the Kalahari Cration. The region was chosen specifically to assess the effects of amalgamation of the Kaapvaal and Zimbabwe Cratons and the subsequent formation of the MesoPalaeoproterozic Magondi-Gweta and Choma-Kaloma Terranes. Over the last decade peridotite xenoliths have been sampled from open pits and drill cores from the Jwaneng, Orapa and Letlhakane (Botswana $92 \mathrm{Ma}$ ) and Venetia (Limpopo Mobile Belt, northern South Africa $\sim 530 \mathrm{Ma}$ ) diamond mines with the aim of determining the timing and processes responsible for the formation and subsequent modification of the SCLM. Samples were subjected to detailed petrological studies and selected samples to whole rock major and trace element and Re-Os isotope analysis and mineral major and trace element and coupled Sr-Nd-Hf isotope analysis.

\section{Results \& Discussion}

Lithological abundances were quantified from the observation of 400 to $>1000$ xenoliths at each location. Garnet lherzolite (clinopyroxene visible in hand specimen) dominate all assemblages with variable abundance of harzburgites and dunites (10-20\%) and subordinate amounts of pyroxeniteswebsterites $(<10 \%)$ and metasomites dominantly formed of amphibole and/or phlogopite $(<5 \%)$. With the notable exception of Letlhakane, the preservation state of xenoliths recovered from open pits is poor with olivine only locally preserved. It is, however, possible to determine the original modal mineralogy. Xenoliths recovered from drill cores from up to $1200 \mathrm{~m}$ below the surface generally have much better preservation such that mineral zonation can be evaluated by electron microprobe.

As reported from elsewhere in the Kalahari Craton, high temperature harzburgites and lherzolites $\left(\mathrm{T}>1150^{\circ} \mathrm{C}\right)$, are usually deformed and have olivine with forsterite contents (Fo) between 88-92. In contrast low temperature garnet harzburgites/lherzolites $\left(\mathrm{T}<1150^{\circ} \mathrm{C}\right)$, have Fo between $92-93.5$. Based on olivine abundance and composition the majority of the SCLM appears to have undergone extensive melt depletion: $30-50 \%$. The xenoltih suites from the different mines record different degrees of Si/orthopyroxene enrichment with for example Letlhakane having up to $40 \%$ orthopyroxene (Fig. 1). There are, however, significant regional variations recorded in the degree of $\mathrm{Si}$-enrichment but as yet no consistent variation with depth among the low temperature peridotites.

Calculated whole rock trace element contents of low temperature peridotites, such as low HREE, coupled with the high Fo olivine imply the low temperature harzburgites/lherzolites originated as residua formed by up to $50 \%$ predominantly in the absence of garnet. This conclusion contrasts with 
the widespread occurrence of clinopyroxene +/- amphibole and/or phlogopite, phases that record trace element enrichment. The majority of the clinopyroxene, amphibole and phlogopite in the garnet lherzolites is not in trace element and $\mathrm{Nd}-\mathrm{Hf}$ isotope equilibrium with coexisting garnet implying metasomatic addition shortly before eruption of the host kimberlite with coupled Nd-Hf isotope ratios implying the involvement of metasomatic melts comparable to the host kimberlites. The exception to this observation are websterites and wehrlites that have coupled $\mathrm{Nd}-\mathrm{Hf}$ isotope systematics indicating formation in the Proterozoic. The majority of the low temperature peridotites with petrographic evidence of significant clinopyroxene, amphibole and phlogopite addition have a within plate signature trace element signature (e.g., low $\mathrm{La} / \mathrm{Nb}, \mathrm{Th} / \mathrm{Nb}$ ) associated with clinopyroxene addition. Harzburgitic samples, in contrast, locally preserve a clear subduction related metasomatic signature (e.g., high $\mathrm{La} / \mathrm{Nb}, \mathrm{Th} / \mathrm{Nb}$ ).

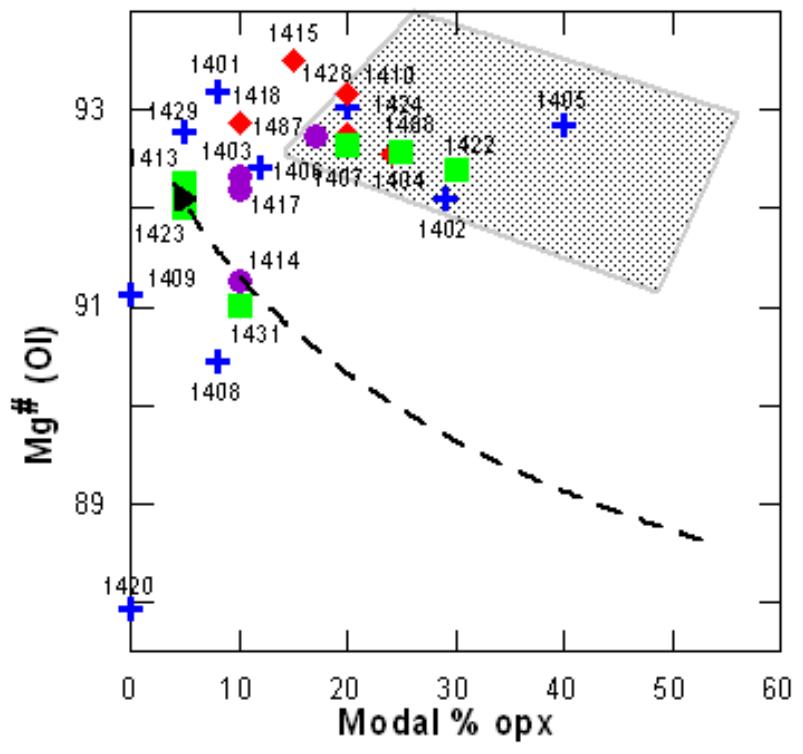

Figure 1: Olivine Mg\# versus modal orthopyroxene content for Letlhakane samples. Black arrow is oceanic melting trend; grey field represents typical Kaapvaal xenoliths assuming 100 $\%$ olivine and opx assemblages (Boyd, 1989). $\mathrm{SiO}_{2}$ enrichment leads to orthopyroxene addition, i.e. points move to the right of the oceanic melting trend. Blue cross: garnet free peridotites, Red diamond: garnet harzburgites, Green square: garnet lherzolites, Purple circle; amphibole garnet lherzolites.

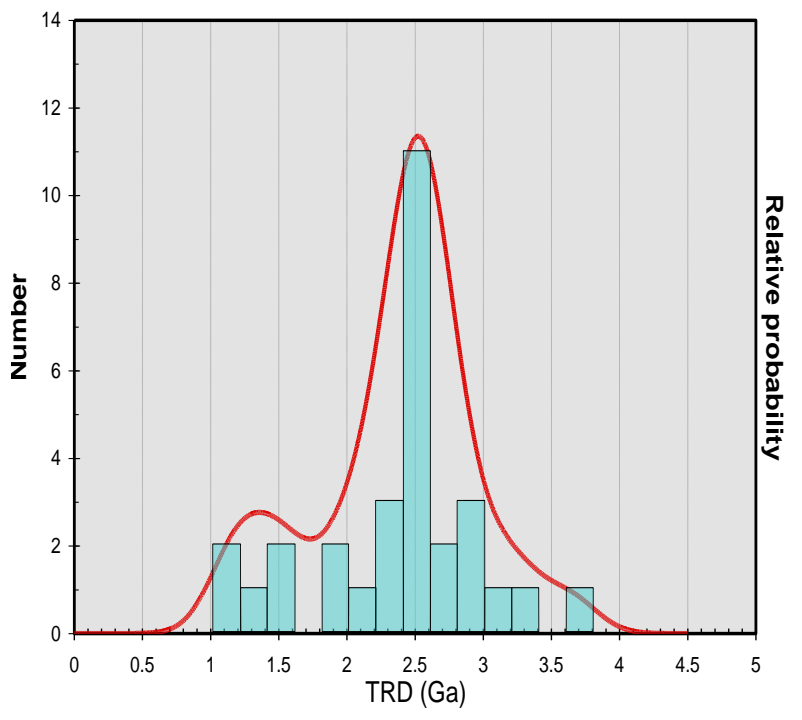

Figure 2: Relative probability plots for rhenium depletion ages of all analysed samples, including Carlson, $1999(\mathrm{n}=30)$. An error of $0.2 \mathrm{Ga}$ is used for calculation of the Gaussian probability curve for all rhenium depletion ages.

Os isotope whole rock data were performed on samples across the region. Rhenium depletion ages range from 1 to $3 \mathrm{Ga}$ with the majority in the region of 2.5-2.7 Ga implying major melt depletion of the peridotitic precursors associated with stabilisation/amalgamation of the craton and Limpopo Belt formation. A finding comparable to previously reported data (e.g., Irvine et al. 2001; Luguet et al., 2015). Major differences between mantle depletion and Re depletion ages, however, imply that many samples have undergone significant redistribution of Re and/or Os. This process is best illustrated in the $530 \mathrm{Ma}$ Venetian suite, which is characterised by significant Si-enrichment. Samples without petrographic and geochemical evidence of clinopyroxene addition immediately prior kimberlite eruption record a coherent isochronous relationship that defines an age of $3.28 \pm 0.17 \mathrm{Ga}$, an age indistinguishable from the mantle depletion ages of the samples but significantly older than $\mathrm{T}_{\mathrm{RD}}$ ages (van der Meer at al. in press; Fig. 2). Samples defining the "isochron" are derived from $~ 50$ to $\sim 170$ $\mathrm{km}$ depth, suggesting coeval melt depletion of the majority of the Venetia lithospheric mantle column. Remaining samples have elevated Re/Os due to Re addition during kimberlite magmatism but have otherwise undergone a similar evolution as the samples that define the "isochron" and have 
overlapping ${ }^{187} \mathrm{Os} /{ }^{188} \mathrm{Os}$ at eruption age: ${ }^{187} \mathrm{Os} /{ }^{188} \mathrm{Os}$ EA. A subset of samples have low Os concentrations, unradiogenic ${ }^{187} \mathrm{Os} /{ }^{188} \mathrm{Os}_{\mathrm{EA}}$ and were effectively Re-free prior to kimberlite magmatism. The combination of Re-Os mobility, preservation of an isochronous relationship, place firm constraints on the formation and subsequent evolution of Venetia lithosphere. Melt depletion and remobilisation of $\mathrm{Re}$ and Os must have occurred within error of the $3.28 \mathrm{Ga}$ mean $\mathrm{T}_{\mathrm{MA}}$ age, potentially related to Si-enrichment. Perhaps most importantly, the refractory peridotites contain significant Re despite recording $>40 \%$ melt extraction suggesting that melting does not remove all Re from peridotites and that $\mathrm{T}_{\mathrm{RD}}$ ages can significantly underestimate the time of melt depletion. The overlap of the $\sim 2.6 \mathrm{Ga} \mathrm{T}_{\mathrm{RD}}$ ages with the time of Limpopo Orogeny is therefore interpreted as purely fortuitous and has no geological significance.

Throughout the region Nd-Hf-Sr isotope relationships recorded by minerals in the peridotites are highly variable. Harzburgitic samples preserve evidence of initial Archaean depletion $(\varepsilon \mathrm{Hf}>300)$ followed by metasomatism that produced LREE enrichment in the late Archaean, mid and late Proterozoic. These events were followed by widespread clinopyroxene, amphibole and phlogopite formation, in some cases associated with kimberlite related magmatism. Clinopyroxene, amphibole, phlogopite and garnet are often in, or close to, isotopic equilibrium at the time of kimberlite eruption with initial ratios that imply equilibration with the host kimberlites or related magmas. In contrast, websterites and pyroxenites record evidence of late Proterozoic formation yielding relatively coherent $\mathrm{Hf}$ and Os $\mathrm{T}_{\mathrm{MA}}$ ages. In summary, the regional SCLM records evidence of melting/metasomatic events at $\sim 3.2,>2.0, \sim 1.5$ and $1.0 \mathrm{Ga}$, ages that coincide with diamond formation and can be linked to regional tectono-magmatic events (Richardson et al 2004; Koornneef et al., 2016; Timmerman et al. 2017).

\section{References}

Aulbach, S., Massuyeau, M., Gaillard, F. (2017). Origins of cratonic mantle discontinuities: A view from petrology, geochemistry and thermodynamic models. Lithos 268-271, 364-382.

Boyd, F.R., 1989. Compositional distinction between oceanic and cratonic lithosphere. Earth and Planetary Science Letters, 96(1-2): 15-26.

Carlson, R., Pearson, D., Boyd, F., Shirey, S., Irvine, G., Menzies, A. and Gurney, J. (1999) Re-Os systematics of lithospheric peridotites: implications for lithosphere formation and preservation, The JB Dawson Volume-Proceedings of the Seventh International Kimberlite Conference, Cape Town. Red Roof Design, Cape Town, pp. 99-108.

Irvine, G.J., Pearson, D.G. and Carlson, R.W. (2001). Lithospheric mantle evolution of the Kaapvaal Craton: A Re-Os study of peridotite xenoliths from Lesotho Kimberlites. Geophysical Research Letters, 28(13): 25052508.

Koornneef, J., Gress, M.U., Harris, J.W. Davies, G.R. (2016). Archaean diamond growth beneath Venetia established by Sm-Nd systematics of individual garnet inclusions. Goldschmidt abstract 1588 .

Luget, A., Behrens, M., Pearson, D.G., Stephan König,, S., Herwartz, D. (2015). Significance of the whole rock $\mathrm{Re}-\mathrm{Os}$ ages in cryptically and modally metasomatised cratonic peridotites: Constraints from HSE-Se-Te systematics. Geochimica et Cosmochimica Acta, 164, 441-463.

Timmerman, S., Koornneef, J.M., Chinn, I.L., Davies, G.R. (2017). Dated diamond growth zones reveal variable recycling of crustal carbon through time. Earth and Planetary Science Letters, 463, 178-188.

Pearson, D. G., \& Wittig, N. (2014). The Formation and Evolution of Cratonic Mantle Lithosphere-Evidence from Mantle Xenoliths. In Treatise on Geochemistry (eds. H. D. Holland and K. K. Turekian). Elsevier, p. 255-292.

Richardson, S.H., Shirey, S.B., Harris, J.W., 2004. Episodic diamond genesis at Jwaneng, Botswana, and implications for Kaapvaal craton evolution. Lithos 77, 143-154.

van der Meer, Q.H.A., Klaver, M., Reisberg, L., Riches, A.J.V., Davies, G.R. (2017). Preservation of an Archaean whole rock Re-Os isochron for the Venetia lithospheric mantle: evidence for rapid crustal recycling and lithosphere stabilisation at $3.3 \mathrm{Ga}$. Geochimica Cosmochimica Acta. Proof stage. 